Ethiopian Journal of Environmental Studies \& Management 9 (1): 97 - 108, 2016.

ISSN:1998-0507

doi: http://dx.doi.org/10.4314/ejesm.v9i1.9

Submitted: September 15, 2015

Accepted: January 14, 2016

\title{
IMPACTS OF CLIMATE CHANGE AND ADAPTATION STRATEGIES IN RURAL COMMUNITIES OF KADUNA STATE, NIGERIA
}

\author{
*ABAJE, I.B. ${ }^{1}$, SAWA, B.A. ${ }^{2}$, IGUISI, E.0. ${ }^{2}$ AND IBRAHIM, A.A. ${ }^{2}$ \\ ${ }^{1}$ Department of Geography and Regional Planning, Federal University Dutsin-Ma, Nigeria \\ ${ }^{2}$ Department of Geography, Ahmadu Bello University, Zaria, Nigeria
}

\begin{abstract}
This study focused on the impacts of climate change on the livelihoods of some selected rural communities of Kaduna state, and the adaptation strategies employed by the people to ameliorate the scourge of climate change. Data for this study were obtained from a direct field study based on the result of 426 questionnaires that were administered to household heads. Descriptive statistics was used to describe the socioeconomic characteristics of the respondents. A five point Likert scale was used to determine the impacts of climate change and adaptation strategies employed by the rural communities. Focus Group Discussions were also held in each Local Government Area in order to obtain in-depth information on the changing climate. The study identified decline in crop yields with a mean score $(\bar{x})$ of 4.01 , increased sickness $(\bar{x}=3.85)$, decrease in soil fertility $(\bar{x}=3.83)$, decline in forest resources $(\bar{x}=$ 3.66) as the most significant impacts of climate change in the area; whereas use of fertilizer/animals dung ( $\bar{x}=3.89)$, water harvesting $(\bar{x}=3.68)$, planting of economic trees and drought resistant crops $(\bar{x}=3.25)$ among others were the most significant and sustainable adaptation strategies adopted by the rural people. The study recommended that awareness programs on climate change challenges should be intensified, and probabilistic analysis of observed rainfall data in order to provide information about the beginning, the end and length of the rainy season, and the amount of available water during the season. Lastly, sustainable adaptation strategies employed by the rural people should be strengthened.
\end{abstract}

Key Words: Adaptation, climate change, impacts, livelihood, resources, rural communities

\section{Introduction}

Climate change in recent decades has caused impacts on natural and human systems on all continents including the oceans (IPCC, 2014). The IPCC (2014) also revealed that evidence of climate change impacts is strongest and most comprehensive for natural systems. In many regions, changes in precipitation or melting snow and ice are altering hydrological systems, affecting both quantity and quality of water resources. In high latitude and high elevation regions, climate change is also causing permafrost warming and thawing.

Climate change impacts according to IPCC (2014) report refer to the effects of extreme weather and climate events and of climate change on natural and human systems. Climate change can have positive 
as well as negative impacts, but negative or adverse impacts are projected to predominate for much of the world. For example, the IPCC (2014) report found out that the negative impacts of climate change on crop yields are more than the positive impacts. The positive impacts relate mainly to high-latitude regions.

In rural areas, the impacts of climate change on settlement patterns, livelihoods and incomes are based on the result of two causal chains of impact. One category of the impact involve extreme events such as floods and storms, as they impact on rural infrastructure and cause direct loss of life; while the other category involve impacts on agriculture or ecosystems on which rural community people depend on (Dasgupta et al., 2014). The impact of climate change on agriculture and ecosystems is through increasing temperature and changes in rainfall patterns (variability and seasonality) as well as through extreme events such as floods and droughts. For example, the Hurricane Stan of October 2005 affected nearly 600,000 people on the Chiapas coast as a result of flooding (SaldañaZorrilla, 2008), while mortality rates of livestock due to the last droughts in Southern Kenya, ranging up to $80 \%$ of livestock in 2009 (Dasgupta et al., 2014).

With specific reference to the northern part of Nigeria, climate change impact varies, depending on regions and sectors but will be more severe where vulnerability to climate change is higher, stress factors are multiple and adaptive capacity is low. Poor communities tend to be more vulnerable especially when located in high risk areas, as they have lower adaptive capacity and depend more on local ecosystem services (Ishaya and Abaje, 2008).
The most devastating impacts of climate change in northern Nigeria include frequent drought and severe floods, altering both surface and underground water supply thereby affecting agriculture and food security; increased infestation of crop by pests and diseases, increased ruralurban migration, increased biodiversity loss, decline in soil conditions, increased health risks and the spread of infectious diseases, and changing livelihood systems (Ishaya and Abaje, 2008; Sawa and Adebayo, 2011).

Traditional coping and adaptation mechanisms may therefore not be sufficient to deal with impact of climate change. Good understanding of the impact of climate change is imperative to facilitating appropriate adaptation strategies to ameliorate the scourge of climate change at all levels. This forms the basis for this research with emphasis on some selected rural communities in Kaduna State.

\section{Study Area}

Kaduna State is located between latitude $09^{\circ} \quad 02^{\prime} \mathrm{N}$ and $11^{\circ} 32^{\prime} \mathrm{N}$ and between longitude $06^{\circ} 15^{\prime} \mathrm{E}$ and $08^{\circ} 38^{\prime} \mathrm{E}$ (Figure 1). The climate is the tropical dryand-wet type, classified by Koppen as Aw (Abaje and Giwa, 2010). The wet season lasts from April through mid-October with a peak in August, while the dry season extends from mid-October of one calendaryear to April of the next (Abaje et al., 2010). The annual average rainfall in the state is about $1323 \mathrm{~mm}$. The spatial and temporal distribution of the rain varies, decreasing from an average of about $1733 \mathrm{~mm}$ in the Southern part of the study area (Kafanchan) to about $1032 \mathrm{~mm}$ in the northern part (Zaria).

Seasonal variation in rainfall is directly influenced by the interaction of two air masses: the relative warm and moist 
tropical maritime $(\mathrm{mT})$ air mass, which originates from the Atlantic Ocean associated with southwest winds in Nigeria; and the relatively cool, dry and stable tropical continental (cT) air mass that originates from the Sahara Desert and is associated with the dry, cool and dusty North-East Trades known as the Harmattan (Sawa, 2002; Abaje et al., 2012). The boundary zone between these two air streams is called the Intertropical Discontinuity (ITD). The movement of the ITD northwards across the state in August (around latitude 21 to $22^{\circ} \mathrm{N}$ ) marks the height of the rainy season in the whole state while its movement to the southernmost part around January/February (approximately at $6^{\circ} \mathrm{N}$ ) marks the peak of the dry season in the state (Abaje et al., 2010; Abaje et al., 2012). The highest average air temperature occurs in April $\left(28.9^{\circ} \mathrm{C}\right)$ and the lowest in December $\left(22.9^{\circ} \mathrm{C}\right)$ through January $\left(23.1^{\circ} \mathrm{C}\right)$. The mean atmospheric relative humidity ranges between $70-90 \%$ and 25 $30 \%$ for the rainy and dry seasons respectively. The highest amount of evaporation occurs during the dry season.

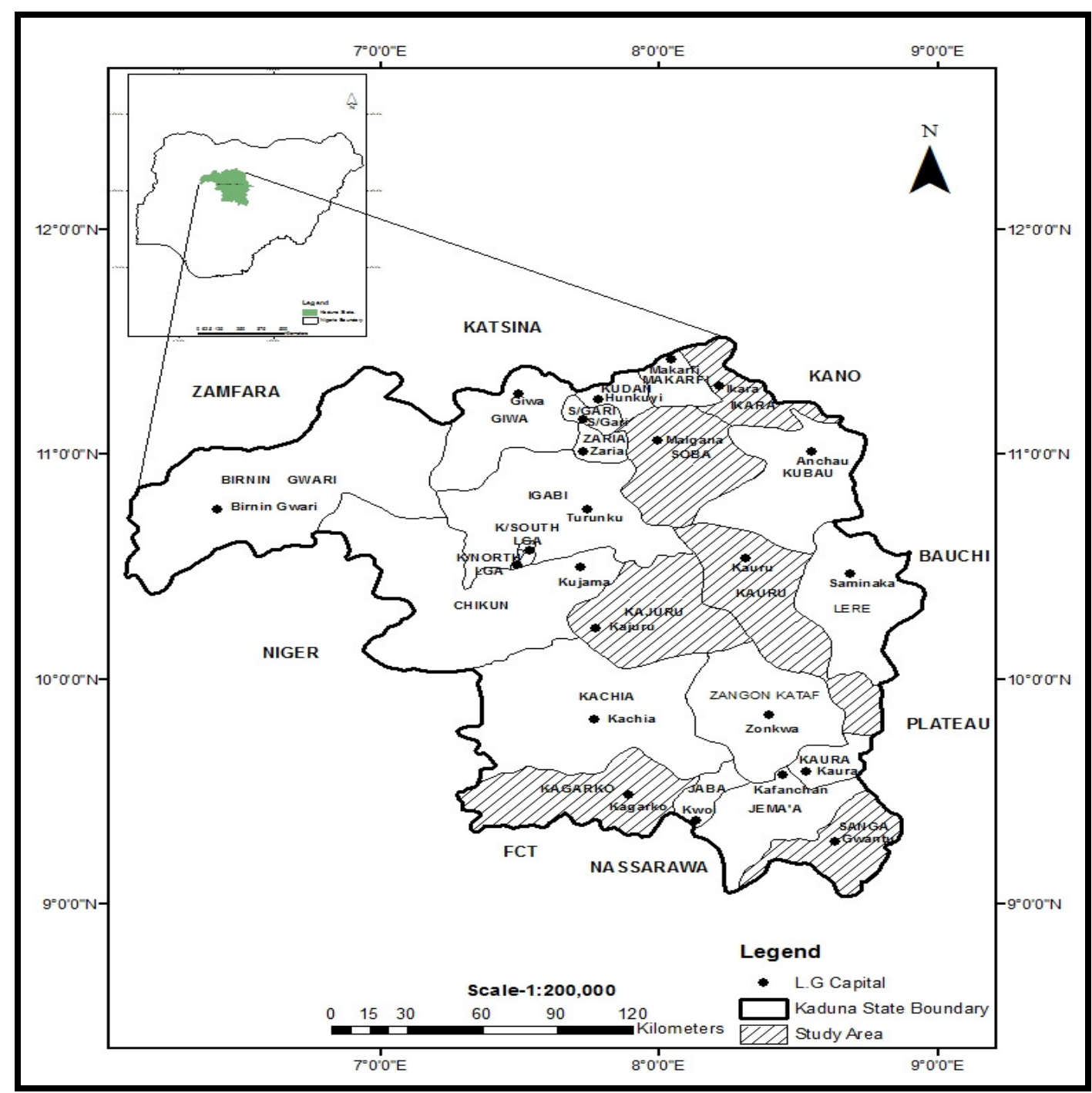

Figure 1: Map of Kaduna State Showing the Study Area 
The geology of the study area is underlain by gneisses, migmatites and metasediments of the Precambrian age which have been intruded by a series of granitic rocks of late Precambrian to lower Palaeozoic age (McCurry, 1989). The entire land structure consists of an undulating Plateau with major rivers in the State including River Kaduna, River Wonderful in Kafanchan, River Kagom, River Gurara and River Galma and several streams.

The soil type in the state consists of red-brown to red-yellow ferruginous tropical soils which are heavily weathered and markedly laterized. They are mostly formed on granite and gneiss parent materials, and on aeolian and many sedimentary deposits. The whole state is covered by the tropical grassland vegetation with the density of trees and other plants decreasing as one move northwards (Abaje, 2007).

\section{Materials and Methods}

Data and information for this research work were obtained from a direct field study. Bartlett et al (2001) method of determining sample size was adopted. The method is computed as:

$$
n_{0}=\frac{(t)^{2} \times(p)(q)}{(d)^{2}}
$$

for sample size of not more than $5 \%$ and

$$
n_{1}=n_{0} /\left(\frac{r}{100}\right)
$$

for adjusted sample size for response rate where: $t=$ value for selected alpha level of 0.025 in each tail which is 1.96

$(p)(q)=$ estimate of variance which is 0.25

$d=$ acceptable margin of error for proportion being estimated which is 0.05

$r=$ anticipated response rate

$n_{0}=$ sample size of not more than $5 \%$
Based on this method, the sample size used with anticipated response rate of $90 \%$ was 426. The questionnaires were proportionally administered to household heads in six LGAs namely: Sanga (52), Kagarko (58), Kajuru (40), Kauru (75), Soba (112), and Ikara (89). These LGAs were selected based on their rurality. Three (3) communities were sampled in each LGA using simple random sampling. The questionnaires were purposively administered to household heads who are 45 years and above, and must have been residing in the community for at least 30 years. The basis for this was to gather information from respondents who have had experiences in climate change over the years and are conscious about the impacts on their livelihoods and the environment (Ishaya and Abaje, 2008; Abaje et al., 2014). Only respondents who were willing and interested on the subject matter were purposively administered questionnaires. Descriptive statistics was used to describe the socioeconomic characteristics of the respondents. In addition, a Focus Group Discussion (FGD) of 9 people in each LGA was held in order to obtain in-depth information on recent environmental changes and adaptation strategies of the rural communities.

Impacts of climate change were determined using a five point Likert Scale. Each respondent was required to respond by ticking any of the options namely: 'strongly agree', 'agree', 'undecided', 'disagree' and 'strongly disagree'.

\section{Results and Discussion}

Socioeconomic Characteristics of Respondents

Majority of the respondents were males $(86.2 \%)$ while only $13.8 \%$ were females (Table 1). Out of the 426 respondents, $37.3 \%$ attended primary school, $12.9 \%$ 
Qur'anic School, $16.0 \%$ have tertiary education, and $18.5 \%$ have secondary education, while $15.3 \%$ have no formal education. The average age of the respondents is 53 years, and majority of them $(86.6 \%)$ are married with an average household size of 10 . The average annual income of the respondents is 195970 . The respondents have been living in the area for an average of 48 years and their major occupations are: farming which represent $58.7 \%$, while $13.6 \%$ engaged in livestock production, civil servants represent $20.2 \%$, traders (5.6\%), while craft and others $1.6 \%$. Based on this result, it is clear that most of the respondents depend heavily on environmental resources for their livelihood.

Table 1: Socioeconomic Characteristics of Respondents

\begin{tabular}{|c|c|c|c|c|}
\hline \multicolumn{2}{|l|}{ Household Characteristics } & Frequency & Percentage & Mean \\
\hline \multirow{2}{*}{ Gender } & Male & 367 & 86.2 & \\
\hline & Female & 59 & 13.8 & \\
\hline \multirow[t]{4}{*}{ Age (Years) } & $45-49$ & 174 & 40.8 & 53 \\
\hline & $50-54$ & 124 & 29.1 & \\
\hline & $55-59$ & 68 & 16.0 & \\
\hline & $\geq 60$ & 60 & 14.1 & \\
\hline \multirow[t]{4}{*}{ Marital status } & Single & 13 & 3.1 & \\
\hline & Married & 369 & 86.6 & \\
\hline & Divorced & 11 & 2.6 & \\
\hline & Widowed & 33 & 7.7 & \\
\hline \multirow[t]{5}{*}{ Level of education } & Primary & 159 & 37.3 & \\
\hline & Secondary & 79 & 18.5 & \\
\hline & Tertiary & 68 & 16.0 & \\
\hline & Qur'anic & 55 & 12.9 & \\
\hline & No formal education & 65 & 15.3 & \\
\hline \multirow[t]{5}{*}{ Household size } & $\leq 5$ & 80 & 18.8 & 10 \\
\hline & $6-10$ & 199 & 46.7 & \\
\hline & $11-15$ & 84 & 19.7 & \\
\hline & $16-20$ & 32 & 7.5 & \\
\hline & $\geq 21$ & 31 & 7.3 & \\
\hline \multirow[t]{5}{*}{ Occupation } & Farming & 250 & 58.7 & \\
\hline & Livestock production & 58 & 13.6 & \\
\hline & Civil servant & 86 & 20.2 & \\
\hline & Trading & 24 & 5.6 & \\
\hline & Craft and others & 8 & 1.9 & \\
\hline \multirow[t]{5}{*}{ Income per annum $(\#)$} & $\leq 150000$ & 220 & 51.6 & 195970 \\
\hline & $150001-300000$ & 143 & 33.6 & \\
\hline & $300001-450000$ & 32 & 7.5 & \\
\hline & $450001-600000$ & 24 & 5.6 & \\
\hline & $\geq 600001$ & 7 & 1.6 & \\
\hline \multirow{5}{*}{$\begin{array}{l}\text { Number of years living in } \\
\text { community }\end{array}$} & $30-34$ & 63 & 14.8 & 48 \\
\hline & $35-39$ & 85 & 20.0 & \\
\hline & $40-44$ & 79 & 18.5 & \\
\hline & $45-49$ & 87 & 20.4 & \\
\hline & $50-89$ & 112 & 26.3 & \\
\hline
\end{tabular}




\section{Perceived Impacts of Climate Change}

The impacts of climate change as perceived by the respondents are presented in Table 2. The most significant impact of climate change as perceived by the rural people studied in the area is decline in crop

yields (ranked 1 ) with a mean score $(\bar{x})$ of 4.01, and all the LGAs were found to be significant with Ikara LGA having the

highest mean score $(\bar{x}=4.75)$ followed by

Soba $(\bar{x}=4.23)$ and Sanga $(\bar{x}=4.21)$, then Kagarko, Kauru, and Kajuru LGAs in that order. The result of this study is in agreement with the studies of Manyatsi et al. (2010), Ozor and Nnaji (2011), Abraham et al. (2012), and Abaje et al. (2014) in which decline in crop yields as perceived by the respondents was significant. All the participants of the FGDs in the study area also complaint of decreasing crop yields in recent years.

Increase in sickness due to extreme heat conditions was the next significant impact of climate change in the study area that was ranked $2^{\text {nd }}$ as perceived by the respondents with a mean score of 3.85 . The result is also in agreement with the findings of Manyatsi et al. (2010), Ozor and Nnaji (2011), and Abaje et al. (2014) where increase in sickness due to extreme heat conditions was significant. The perceived respondents on decrease in soil fertility and decline in forest resources were significant with a mean score of 3.83 and 3.66 respectively. The mean scores for each of the LGA on those two items were all significant. The fact that most of the respondents are farmers, couple with their long time experience with the environment made it possible for them to easily notice the impact of climate change on those resources (soil and vegetation). A number of factors that contributes to declining soil fertility and forest resources in the area include: bush burning, cutting down of the trees and overgrazing.

Other significant impacts of climate change as perceived by the rural people in the study area are crop infestation and diseases $(\bar{x}=3.64)$, decreasing/drying of water sources $(\bar{x}=3.62)$, and frequent occurrences of floods during the raining season $(\bar{x}=3.53)$. All these items were in agreement with the results of Manyatsi et al. (2010), Ozor and Nnaji (2011), Abaje $e t$ al. (2014), and Udeh (2014). Decreasing/drying of water sources as perceived by the respondents may not be unconnected with decreased in length of the rainy season and the high inter-annual rainfall variability in northern Nigeria. The report of NIMET (2012) indicated that the length of the rainy season has reduced while annual total rainfall is increasing or about the same, with high rainfall variability in the northern state. Climate change has led to rural-urban migration of youths with a significant impact factor of 3.28. This is in variance with the result of Abraham et al. (2012) that climate change is not leading to rural-urban migration in the rural Guinea savanna region of Nigeria.

On the other hand, the yearly rains are not supporting crop production as before, increasing cost of food crops, frequent occurrence of droughts during the raining season, change in livelihood system, and increasing death of livestock were not perceived as significant impacts of climate change in the study area by the respondents. 
Table 2: Respondents' Perceived Impacts of Climate Change

\begin{tabular}{|c|c|c|c|c|c|c|c|c|c|}
\hline \multirow{2}{*}{$\mathrm{S} / \mathrm{NO}$} & \multirow{2}{*}{ Statement } & \multicolumn{8}{|c|}{ Mean Scores } \\
\hline & & Sanga & Kagarko & Kajuru & Kauru & Soba & Ikara & Average & Rank \\
\hline 2 & The yearly rains are not supporting crop production as before & 2.79 & 2.98 & 2.88 & 2.68 & 2.87 & 2.87 & 2.84 & 12 \\
\hline 4 & Cost of food crops are increasing because of climate change. & 2.85 & $3.16^{*}$ & 2.88 & 2.89 & 2.94 & 2.73 & 2.91 & 9 \\
\hline 5 & Climate change has led to rural-urban migration of youths. & $3.85^{*}$ & 2.97 & $3.60 *$ & 2.61 & $3.55^{*}$ & $3.09 *$ & $3.28 *$ & 8 \\
\hline 6 & Climate change has led to decline in forest resources. & $3.94 *$ & $3.26^{*}$ & $4.03 *$ & $3.44 *$ & $3.32 *$ & $3.94 *$ & $3.66^{*}$ & 4 \\
\hline 7 & Frequent occurrences of floods during the raining season. & $3.94 *$ & $3.33 *$ & $3.73 *$ & $3.08 *$ & 2.91 & $4.19 *$ & $3.53 *$ & 7 \\
\hline 10 & Climate change has led to changes in livelihood system & 2.96 & 2.69 & $3.13 *$ & 2.80 & 2.93 & 2.83 & 2.89 & 10 \\
\hline 11 & There is decrease in soil fertility & $4.29 *$ & $3.57 *$ & $3.73 *$ & $3.69 *$ & $3.25^{*}$ & $4.48 *$ & $3.83 *$ & 3 \\
\hline 12 & Death of livestock is increasing & 2.87 & 2.67 & 2.93 & 2.96 & 2.76 & 2.98 & 2.86 & 11 \\
\hline 13 & Increased sickness due to extreme heat conditions & $4.31 *$ & $3.98 *$ & $3.73 *$ & $3.36 *$ & $4.00 *$ & $3.71 *$ & $3.85^{*}$ & 2 \\
\hline
\end{tabular}

*Significant impacts 
Adaptation Strategies Adopted in Combating Impacts of Climate Change

The rural people's livelihoods are highly dependent on natural resources, which are climate sensitive, for crop and livestock production, and field observations show that climate change is already having severe impacts on the studied communities. Table 3 shows the adaptation strategies adopted by the rural people in combating the impacts of climate change in the various communities. The most significant adaptation strategies adopted by the rural communities of the study area are the use fertilizer/animals dung

on farm to improve crop yield $(\bar{x}=3.89)$ and water harvesting during the raining season $(\bar{x}=3.68)$. These two strategies are found to be significant across all the LGAs. This is followed by, planting of crop varieties with a wide range of maturity and

climatic variability tolerance $(\bar{x}=3.25)$ in which all the LGAs were significant with the only exception of Kauru and Ikara LGAs. Praying for God to intervene in the

situation $(\bar{x}=3.14)$, selling of livestock in order to augment cost of crop production and other domestic activities, and then irrigation farming on flood plains/fadama during dry season in order to have surplus food crops were the other significant adaptation strategies adopted by the rural communities in the study area. All the significant cases were in agreement with the results obtained by Farauta et al. (2011), Abaje et al. (2014), and Udeh (2014) in various researches that dealt with climate change adaptation strategies.

Selling of livestock to augment cost of crop production is not a sustainable strategy for combating the impacts of climate change. This is because most of the rural communities especially in the northern part of the study area rely on these animals (donkeys, cattle and camels) as a source of draught for ploughing, conveyance of animals' dung (manure) to the farm and harvested crops from farms among others. They equally serve as source of transportation of people and goods to markets and other communities. But in a situation where these animals are sold, most of the communities have to resort to manual farming especially if they do not have enough money to hire tractors or oxen for draught power (Abaje et al., 2014). In terms of praying for God to intervene as adaptation strategy, a participant practicing Islam from Malikanchi community of Ikara LGA during the FGD said that:

Whenever there is late onset of the rainy season, or the occurrence of drought (dry spell) during the rainy season, or any form of weather and climate anomalies, the community leader will then call for prayers. The Muslims will pray in their mosques while the Christians pray in their churches and our prayers are always answered by Almighty Allah (God). 
Table 3: Adaptation Strategies Adopted in Minimizing the Impacts of Climate Change

\begin{tabular}{|c|c|c|c|c|c|c|c|c|c|}
\hline \multirow{2}{*}{$\mathrm{S} / \mathrm{NO}$} & \multirow{2}{*}{ Statement } & \multicolumn{8}{|c|}{ Mean Scores } \\
\hline & & Sanga & Kagarko & Kajuru & Kauru & Soba & Ikara & Average & Rank \\
\hline 2 & Planting of drought resistant crops & 3.06 & 3.03 & 3.65 & 1.99 & 3.32 & 2.44 & 2.92 & 8 \\
\hline 4 & Involvement in community and individual level savings & 2.35 & 3.31 & 3.60 & 2.09 & 3.09 & 2.21 & 2.78 & 9 \\
\hline 5 & $\begin{array}{l}\text { Planting of crop varieties with a wide range of maturity and } \\
\text { climatic variability tolerance }\end{array}$ & 3.58 & 3.64 & 3.93 & 2.29 & 3.48 & 2.57 & $3.25 *$ & 3 \\
\hline 6 & Using herbicides to control weeds on the farm & 2.06 & 2.66 & 3.53 & 1.89 & 2.45 & 2.17 & 2.46 & 12 \\
\hline 9 & $\begin{array}{l}\text { Access to formal and informal credit community-based } \\
\text { loaning institution in your community }\end{array}$ & 2.12 & 2.38 & 3.35 & 1.84 & 2.46 & 2.28 & 2.41 & 13 \\
\hline 10 & Praying for God to intervene & 3.37 & 3.19 & 4.00 & 1.95 & 2.95 & 3.38 & $3.14 *$ & 4 \\
\hline 11 & $\begin{array}{l}\text { You have been attending enlightenment programs on climate } \\
\text { change }\end{array}$ & 2.37 & 2.47 & 3.65 & 2.15 & 2.96 & 1.53 & 2.52 & 11 \\
\hline 12 & Water harvesting during the raining season & 3.79 & 4.05 & 4.28 & 3.35 & 3.48 & 3.10 & $3.68 *$ & 2 \\
\hline
\end{tabular}

*Significant adaptation strategies 
On the other hand, the use of modern storage facilities was not a significant adaptation strategy for the study area but it was found to be significant among the rural people of Sanga, Kagarko, Kajuru and Soba LGAs. In terms of enlightenment on the use of modern storage facilities, it was only significant for Kagarko and Kajuru LGAs. Others that are not significant according to the respondents in the various communities are involvement in community and individual level savings, planting of economic trees to generate income, attending enlightenment programs on climate change, the use of herbicides to control weeds on the farm, and access to formal and informal credit communitybased loaning institution in the various communities.

\section{Conclusion and Policy Recommendations}

The frequency of climate change is increasing both in terms of extreme weather events and gradual changes in climate, and consequently aggravating the impacts on the major occupations of the rural people (crop and livestock production) and other livelihood assets they depend upon that are climatesensitive.

The most significant impacts are decline in crop yields, increased sickness due to extreme heat conditions, decrease in soil fertility and forest resources, occurrence of floods during the raining season among others. On the other hand, the most significant adaptation strategies adopted by the rural people that are sustainable are water harvesting during the raining season, used of fertilizer/animals dung to improve crop yield, engaging in irrigation agriculture during dry season, planting of economic trees and drought resistant crops, planting of crop varieties with a wide range of maturity and climatic variability tolerance are sustainable adaptation strategies that should be adopted.

The study recommends that awareness programs on climate change challenges should be intensified. This is because the ability to effectively respond to climate change challenges is determined by the quality of information available to the people and how easily they can access it. Due to the fact that the major occupation of the rural people is farming, probabilistic analysis of existing series of observed rainfall and temperature data is very important. This would provide useful information about the beginning, the end and length of the rainy season, the amount of available water during the season. Such knowledge is pertinent to the introduction of new and more productive crop varieties that can cope with soil water and temperature stress, and for introduction of improved farming systems as adaptation strategies. Lastly, there is need to further study the vulnerability and adaptive capacity of the rural communities to the changing climate in order develop an adaptation framework that could enhance the resilience of the vulnerable people.

\section{References}

Abaje, I.B. and Giwa, P.N. (2010). Flood Risk Assessment and Vulnerability in Kafanchan Town, Jema'a Local Government Area of Kaduna State, Nigeria. International Journal of Sustainable Development, 3(1): 94100.

Abaje, I.B. (2007). Introduction to Soils and Vegetation. Kafanchan: Personal Touch Productions.

Abaje, I.B., Ati, O.F. and Iguisi, E.O. (2012). Recent Trends and Fluctuations of Annual Rainfall in 
the Sudano-Sahelian Ecological Zone of Nigeria: Risks and Opportunities. Journal of Sustainable Society, 1(2): 44-51.

Abaje, I.B., Ishaya, S. and Usman, S.U. (2010). An Analysis of Rainfall Trends in Kafanchan, Kaduna State, Nigeria. Research Journal of Environmental and Earth Sciences, 2(2): 89-96.

Abaje, I.B., Sawa, B.A. and Ati, O.F. (2014). Climate Variability and Change, Impacts and Adaptation Strategies in Dutsin-Ma Local Government Area of Katsina State, Nigeria, Journal of Geography and Geology, 6(2): 103-112.

Abraham, F., Bamidele, F.S., Adebola, A.J., and Kobe, I.H. (2012). Climate Change Mitigation Activities and Determinants in the Rural Guinea Savannah of Nigeria. Sustainable Agriculture Research, 1(2): 170-177.

Bartlett, J.E., Kotrlik, J.W. and Higgins, C.C. (2001). Organizational Research: Determining Appropriate Sample Size in Survey Research. Information Technology, Learning, and Performance Journal, 19(1): 4350

Dasgupta, P., Morton, J., Dodman, D., Karapinar, B., Meza, F., RiveraFerre, M.G. and Vincent, K. (2014). Rural Areas. Climate Change 2014: Impacts, Adaptation and Vulnerability. Contribution of Working Group II to the Fifth Assessment Report of the Intergovernmental Panel on Climate Change. United Kingdom and New York, NY: Cambridge University Press.

Farauta, B.K., Egbule, C.L., Idrisa Y.L. and Agu, V.C. (2011). Farmer's perceptions of climate change and adaptation strategies in northern Nigeria: An empirical assessment. African Technology Policy Studies Network. Research Paper No. 15. Retrieved from http://www.atpsnet.org/Files/rps15.p df

IPCC. (2014). Summary for policymakers. In Field, C.B., Barros, V.R., Dokken, D.J., Mach, K.J., Mastrandrea, M.D., Bilir, T.E. and White, L.L. (Eds.). Climate Change 2014: Impacts, Adaptation, and Vulnerability (pp. 1-32.). Contribution of Working Group II to the Fifth Assessment Report of the Intergovernmental Panel on Climate Change Cambridge University Press, Cambridge, United Kingdom and New York, NY, USA.

Ishaya, S. and Abaje, I.B. (2008). Indigenous People's Perception on Climate Change and Adaptation Strategies in Jema'a Local Government Area of Kaduna State, Nigeria. Journal of Geography and Regional Planning, 1(8): 138-143.

Manyatsi, A.M., Mhazo, N. and Masarirambi, M.T. (2010). Climate variability and change as perceived by rural communities in Swaziland. Research Journal of Environmental and Earth Sciences, 2(3): 164-169.

McCurry, P. (1989). A General Review of the Geology of the Precambrian to the Lower Palaezoic Rocks of Northern Nigeria. In Kogbe, C.A. (Ed.). Geology of Nigeria. $2^{\text {nd }}$ Revised Edition (pp 13-37). Jos: Rock View (Nigeria) Limited.

Nigerian Meteorological Agency, NIMET. (2012). 2012 Nigeria Climate Review (59 pp). Nigerian Meteorological Agency (NIMET), Abuja. 
Ozor, N. and Nnaji, C. (2011). The role of extension in agricultural adaptation to climate change in Enugu State, Nigeria. Journal of Agricultural Extension and Rural Development, 3(3): 42-50.

Sawa, B.A. (2002). Trend in the Temporal Variability of Occurrence of Wet and Dry Spells North of Latitude $10^{\circ} \mathrm{N}$ in Nigeria. In Iguisi, E.O. (Ed.). The Zaria Geographer, 15(1): 34-41.

Sawa, B.A. and Adebayo, A.A. (2011). The Impact of Climate Change on
Precipitation Effectiveness Indices in Northern Nigeria. Research Journal of Environmental and Earth Sciences, 3(5): 481-486.

Udeh, L.E. (2014). Assessment of Farmers' Perception and Adaptation Strategies to Climate Change in Kano State, Nigeria. Unpublished Ph.D. Thesis, Department of Geography, Ahmadu Bello University, ZariaNigeria. 